\title{
PkM Kopontren Daarul Rahman Cipedak Jagakarsa Jakarta Selatan Melalui Kewirausahaan Syariah Berbasis Smartphone
}

\author{
Yunika Murdayanti ${ }^{1}$ dan Susi Indriani ${ }^{2}$ \\ ${ }^{1}$ D3 Akuntansi, Fakultas Ekonomi, Universitas Negeri Jakarta, Jl. Rawamangun Muka Jakarta \\ Timur 13220, Indonesia \\ ${ }^{2}$ S1 Pendidikan Ekonomi, Fakultas Ekonomi, Universitas Negeri Jakarta, Jl. Rawamangun \\ Muka Jakarta Timur 13220, Indonesia
}

\begin{abstract}
The existence of Pesantren Cooperation can be viewed through three dimensions, such as a supporter of the economic life mechanism of Pesantren (Islamic Institution), as a coaching cadre of rural cooperation and as a socio-economic stimulator of rural communities around boarding school. However, there is a problem, the lack of access to knowledge and entrepreneurship education programs for students will raise worries of intellectual understanding and the increase of their soft skills. The method of implementing this service is carried out at the cooperation of Pesantren Daarul Rahman in South Jakarta through interviews, lectures on training material, practices and discussions on inventory and financial training using information technology applications both with Ms. Excell computer programs and smartphone-based digital applications. Achieving the results of this activity is an increase in the ability of managerial skills and have the ability to use information technology in its application to digital financial records.
\end{abstract}

Keywords: Entrepreneurship, Information Technology, Pesantren Cooperation

\begin{abstract}
Abstrak-Eksistensi Koperasi Pondok pesantren dapat ditinjau melalui tiga dimensi yaitu sebagai pendukung mekanisme kehidupan ekonomi Pondok pesantren, sebagai pembinaan kader koperasi pedesaan dan sebagai stimulator sosio-ekonomi masyarakat desa di sekitar Ponpes. Namun terdapat permasalahan yaitu minimnya akses pengetahuan dan program pendidikan kewirausahaan bagi para santri akan memunculkan kekhawatiran akan semakin tertinggalkan pemahaman intelektual maupun keterasahan softskill mereka. Metode pelaksanaan pengabdian ini dilakukan di Koperasi Pondok Pesantren Daarul Rahman Jakarta Selatan melalui wawancara, ceramah mengenai materi pelatihan, praktik dan diskusi pelatihan pencatatan persediaan dan keuangan menggunakan aplikasi teknologi informasi baik dengan program komputer ms excell dan aplikasi digital berbasis smartphone. Pencapaian hasil kegiatan ini adalah peningkatan kemampuan keterampilan manajerial dan memiliki kemampuan menggunakan teknologi informasi dalam pengaplikasiannya pada pencatatan keuangan digital.
\end{abstract}

Kata kunci : Kewirausahaan, Teknologi Informasi, Koperasi Pondok Pesantren

\section{PENDAHULUAN}

Pendidikan kewirausahaan dan pembentukan inkubator bisnis merupakan salah satu cara yang dilakukan untuk bisa mengembangkan keterampilan pengelolaan aset yang dimiliki oleh pesantren. Praktik kewirausahaan dalam bentuk koperasi dipilih agar kegiatan dapat memberikan manfaat baik secara aspek keuangan dan keahlian usaha yang ditujukan bagi santri untuk santri dan oleh santri. Sebagai perwujudan dari pemberdayaan ekonomi, banyak pesantren yang telah mendirikan koperasi pondok pesantren (kopontren). Eksistensi Koperasi Pondok pesantren dapat ditinjau melalui tiga dimensi yaitu sebagai pendukung mekanisme kehidupan ekonomi Pondok pesantren, sebagai pembinaan kader koperasi pedesaan dan 
sebagai stimulator sosio-ekonomi masyarakat desa di sekitar Ponpes. Dewasa ini, Kopontren telah berkembang dan menjadi semacam representasi lembaga ekonomi santri yang diinisiasi secara bottom up dengan ciri kemandirian yang khas (Marsudi, 2011).

Perkembangan koperasi pondok pesantren diikuti juga oleh banyaknya pondok pesantren yang sudah berkembang dengan memiliki sejumlah santri yang bergabung di pondok pesantren tersebut. Populasi Pondok Pesantren terbesar berada di Provinsi Jawa Barat, Jawa Timur, Jawa Tengah dan Banten yang berjumlah78,60\% dari jumlah seluruh Pondok Pesantren di Indonesia. Dengan rincian Jawa Barat 7.624 (28\%), Jawa Timur 6.003 (22,05\%), Jawa Tengah 4.276 (15,70\%), dan Banten 3.500 (12,85\%). Dari seluruh Pondok Pesantren yang ada, berdasarkan tipologi Pondok Pesantren, terdapat sebanyak 14.459 (53,10\%) Pondok Pesantren Salafiyah, dan 7.727 (28,38\%) Khalafiyah/Ashriyah, serta 5.044 (18,52\%) sebagai Pondok Pesantren Kombinasi.

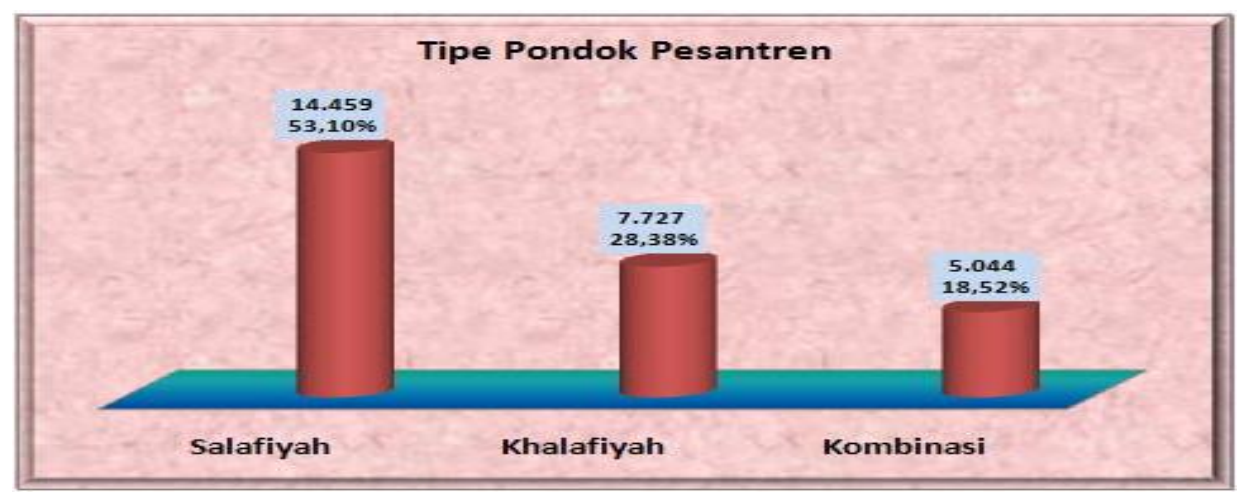

Gambar 1. Jumlah Pondok Pesantren 2011-2012

Survey Bank Indonesia seperti dikutip https://economy.okezone.com memperlihatkan bahwa sumber dana pesantren yang terbesar masih dari iuran santri, sementara kontribusi dari unit usaha masih relative kecil, yakni baru 12\%. Selain itu, sebagian sumber dana pesantren juga berasal dari bantuan pemerintah. Kecilnya kontribusi unit usaha disebabkan karena terdapat beberapa kendala dalam pengembangan ekonomi pesantren. Kendala tersebut antara lain pemasaran, jaringan, kapabilitas, dan permodalan. Program pemberdayaan pesantren merupakan suatu perwujudan strategi pemberdayaan ekonomi melalui komunitas, antara lain pesantren dan UMKM. Roadmap tersebut berisi programprogram peningkatan kapasitas pesantren disertai kerangka waktu pencapaian, yaitu penyusunan standar akuntansi pesantren; pilot project dan replikasi usaha; penyusunan virtual market; penyusunan repository knowledge; dan pendirian holding pesantren.

Dalam pelaksanaan roadmap tersebut, sejak tahun ini BI telah melaksanakan pilot project dan replikasi pengembangan usaha pesantren di 62 pesantren seluruh Indonesia dengan melibatkan 32 Kantor Perwakilan BI. BI menjalin kerja sama dengan beberapa pesantren mentor untuk melakukan pendampingan di pesantren binaan. Selain itu, BI juga menjalin kerja sama dengan beberapa kementerian dalam program pengembangan ekonomi pesantren. Dalam 
pilot project pengembangan usaha ada lima Jenis usaha yang akan dikembangkan, yaitu pertanian berkesinambungan, pengolahan daur ulang sampah, pengolahan air minum, biogas dan pengembangan ekonomi dan jasa kreatif.

Pondok pesantren yang menjadi sasaran strategis adalah Pondok pesantren Daarul Rahman Jakarta Selatan. Ponpes Daarul Rahman berdiri sejak 11 Januari 1975 dari tanah waqaf seluas 5.085 meter persegi dari H. Abdurrahman Naidi kepada Kiai Syukron Ma'mun terletak di jl. Senopati Dalam Kebayoran Baru Jakarta Selatan dan sejak tahun 2009 berpindah ke jl. Cipedak Muhammad Kahfi II Kavling DKI , Jagakarsa Jakarta Selatan. Ponpes Daarul Rahman saat ini telah mencapai 800 santri, baik santri putra dan santri putri. Mereka telah banyak meraih prestasi, seperti juara lomba pidato bahasa Indonesia, Arab, dan Inggris tingkat DKI. Pesantren ini juga pernah dihadiri oleh Kemenkop (Asdep Pengembangan Kewirausahaan Kemenkop dan UKM) yang bertujuan mendorong santri untuk belajar dan memulai jadi wirausaha, pada acara Musyawarah Besar ke IX PP IKDAR ( Ikatan Keluarga Alumni Daarul Rahman).

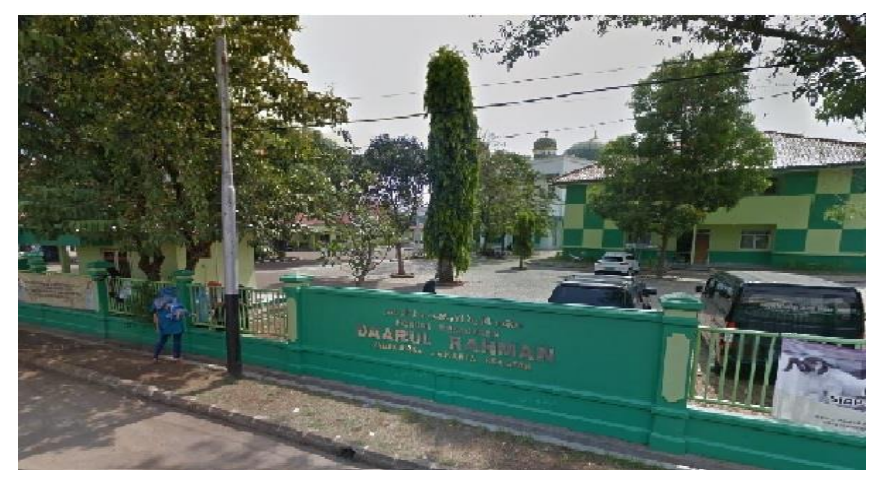

Gambar 2. Ponpes Daarul Rahman, Jln Cipedak Jagakarsa, Kav DKI Jakarta selatan

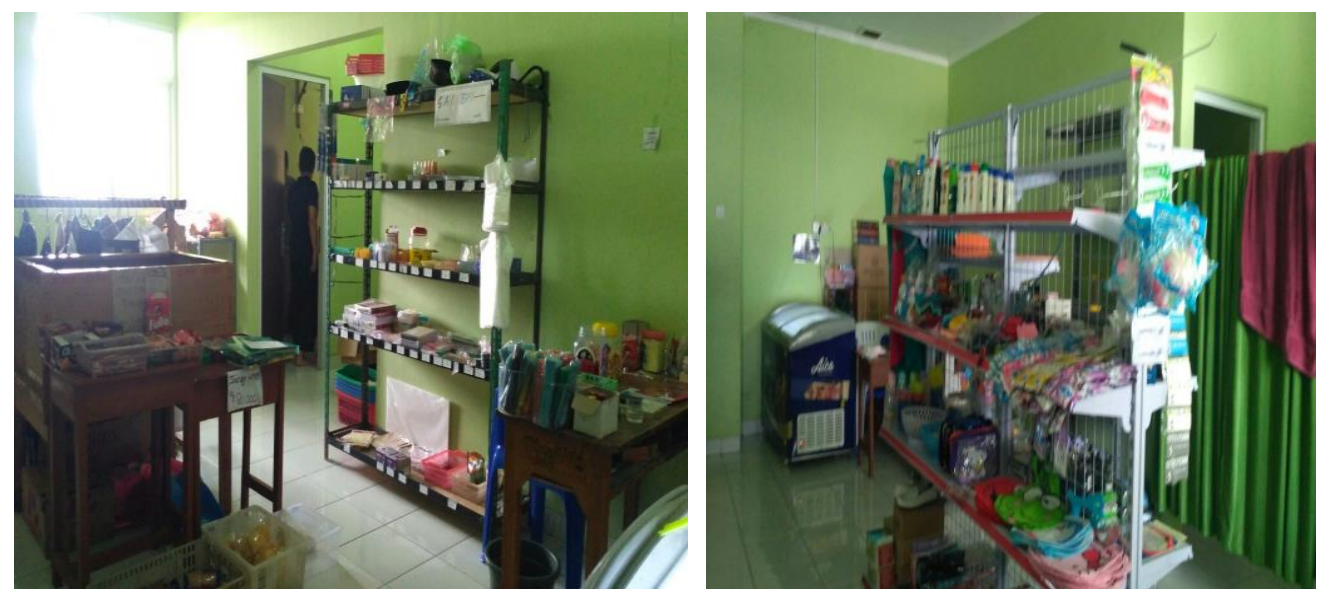

Gambar 3. Koperasi putera dan koperasi puteri Ponpes Daarul Rahman, Cipedak Jagakarsa

Sebagai bentuk partisipasi aktif kalangan akademisi dalam ikut mengembangkan potensi ekonomi di lingkungan pesantren maka pendidikan pengelolaan aset koperasi yang sudah berkembang menjadi hal yang penting untuk dilakukan secara berkelanjutan. Hal ini merupakan bentuk pemberdayaan ekonomi secara langsung yang manfaatnya akan sangat berguna bagi 
ekonomi dalam skala kecil dan besar bagi lingkungan pesantren dan sekitarnya. Berdasarkan kunjungan dan pendalaman atas kebutuhan pengelolaan aset koperasi yang dilakukan secara langsung ke pesantren maka diidentifikasi beberapa permasalahan yang dihadapi :

A. Aspek pengelolaan aset koperasi

Koperasi di pondok pesantren ini sudah lama beroperasi, namun belum mengalami perkembangan yang signifikan terutama dalam pengelolaan manajemen secara professional. Manajemen Pengelolaan yang masih rendah yang ditunjukkan dengan indikator pertanggungjawaban yang masih terpusat dan pencatatan keuangan yang masih manual serta keterbatasan dana.

B. Aspek pendidikan kewirausahaan

Rendahnya pengetahuan pendidikan kewirausahaan yang mengakibatkan minimnya keterampilan menjadi seorang wirausaha yang tangguh. Masih ditemukan adanya kelemahan dalam pengetahuan akan kewirausahaan. Minimnya akses pengetahuan dan program pendidikan kewirausahaan bagi para santri akan memunculkan kekhawatiran akan lambatnya perkembangan koperasi sebagai entitas ekonomi.

C. Aspek Tekhnologi informasi

Masih minimnya pemanfataan teknologi seperti Komputer untuk mempermudah pengelolaan dalam manajemen koperasi. Layanan koperasi juga masih terbatas pada santri sebagai angota maupun sebagai konsumen. Teknologi informasi sudah terbukti memberi kesempatan membangun usaha secara efisien sekaligus memberikan keuntungan yang wajar belum mendapatkan porsinya baik dari sisi pencatatan administrasi keuangan dan juga aplikasi pemasaran.

\section{TINJAUAN PUSTAKA}

\subsection{Kewirausahaan}

Wirausaha adalah seorang pembuat keputusan yang membantu terbentuknya system ekonomi perusahaan yang bebas. Sebagian besar pendorong perubahan, inovasi dan kemajuan di perekonomian kita akan datang dari para wirausaha; orang yang memiliki kemampuan untuk mengambil resiko dan mempercepat pertumbuhan ekonomi. Kewirausahaan (Entrepreneurship) adalah kemampuan kreatif dan inovatif yang dijadikan dasar, kiat, dan sumber daya untuk mencari peluang menuju sukses.

\subsection{Kegiatan Kewirausahaan Menurut Pandangan Islam}

Islam memang tidak memberikan penjelasan secara eksplisit terkait konsep tentang kewirausahaan (entrepreneurship) ini, namun di antara keduanya mempunyai kaitan yang cukup erat; memiliki ruh atau jiwa yang sangat dekat, meskipun bahasa teknis yang digunakan berbeda. Dalam Islam digunakan istilah kerja keras, kemandirian (biyadihi), dan tidak cengeng. 
Setidaknya terdapat beberapa ayat al-Qur'an maupun Hadis yang dapat menjadi rujukan pesan tentang semangat kerja keras dan kemandirian ini, seperti; "Amal yang paling baik adalah pekerjaan yang dilakukan dengan cucuran keringatnya sendiri, 'amalurrajuli biyadihi (HR.Abu Dawud)"

\subsection{Wirausaha Syariah}

Dalam wirausaha berbasis syariah, ajaran Islam harus menjadi landasan yang kukuh seperti dalam memantapkan hati nurani umat islam bahwa apa yang dikerjakan secara moral dari segi keimanan adalah benar, dalam memotivasi kerja dan sumber inspirasi untuk melahirkan prakarsa dan kreatifitas dalam semua usaha untuk mencapai kebahagiaan dunia dan akhirat, menjadi kendali dalam membangun dan menjalankan bisnis dan menetapkan bisnisbisnis yang ingin dicapai

\subsection{Karakteristik wirausaha syariah}

1. Proaktif adalah suka mencari informasi yang ada berhubungan dengan usaha yang digeluti

2. Produktif, Salah satu kunci untuk sukses adalah selalu ingin mengeluarkan uang untuk halhal yang produktif. Tidak sembarang mengeluarkan uang, teliti, cermat, dan penuh dengan perhitungan dalam memutuskan pengeluaran .

3. Pemberdaya. Seorang wirausaha adalah pemberdaya atau memberdayakan orang lain.

4. Tangan di atas, Sebagai entrepreneur yang berbasis syariah umumnya memiliki karakter tangan diatas (suka memberi).

5. Takwa, Seorang muslim dalam berbisnis harus selalu mengingat Allah dalam aktifitas mereka.

6. Amanah adalah dapat dipercaya dan bertanggung jawab

7. Keadilan, Salah satu prinsip dalam bisnis yang harus diterapkan adalah sikap adil

\subsection{Koperasi Syariah}

Kementrian Koperasi UKM RI tahun 2009 pasal 1, menyatakan bahwa Koperasi jasa keuangan syariah adalah koperasi yang kegiatan usahanya bergerak di bidang pembiayaan, investasi, dan simpanan sesuai dengan pola bagi hasil (syariah). Koperasi syariah sendiri lahir sejak menjamurnya pendirian beberapa Baitul Maal WatTamwiil (BMT) yang pada pertama kali dirintis oleh BMT Bina Insan Kamil pada tahun 1992. BMT berbasis kegiatan ekonomi kerakyatan dengan falsafah yang sama yaitu dari anggota oleh anggota untuk anggota maka berdasarkan Undang-undang nomor 25 tahun 1992 tersebut berhak menggunakan badan hukum koperasi 


\section{METODE}

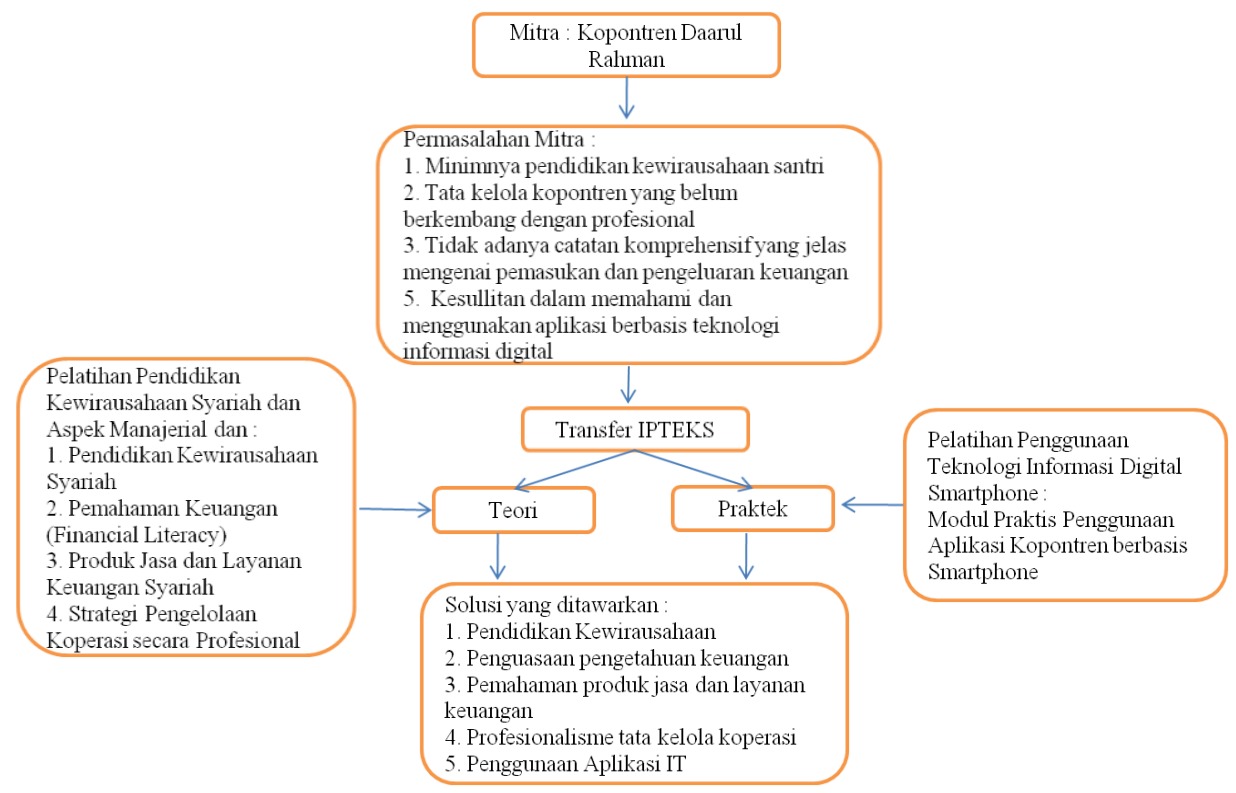

Gambar 4. Kerangka pemecahan Masalah untuk koperasi pesantren Daarul Rahman

Informasi mengenai beberapa permasalahan yang dihadapi oleh koperasi pondok pesantren diatas tentunya harus sesegera mungkin untuk diatasi sebagai salah satu solusi dalam meningkatkan pendidikan kewirausahaan, keterampilan manajerial, keuangan dan teknologi informasi koperasi pondok pesantren. Melalui program usulan kegiatan IPTEKS ini dan berdasarkan analisis kebutuhan yang telah dilaksanakan, tim pengabdi mencoba menawarkan solusi terhadap permasalahan tersebut dengan sentuhan Ipteks, yaitu melalui kegiatan pokok 1) peningkatan pemahaman dan keterampilan koperasi pesantren, 2) peningkatan kemampuan penggunaan teknologi informasi smartphone, 3) peningkatan kemampuan manajerial mitra.

Transfer Ipteks yang dilakukan tim pada tiap tahapan yang diterima oleh mitra dilakukan melalui proses, mendengar, mengetahui, mencoba, mengevaluasi, menerima, meyakini dan melaksanakan yaitu :

1. Wawancara dengan pimpinan pondok pesantren yang bersedia untuk dibantu pengelolaan koperasi dan keuangannya untuk menjadi lebih efektif dan efisien.

2. Ceramah dan tatap muka mengenai pengenalan pendidikan kewirausahaan syariah (ISIEMENT) dan pengelolaan manajerial baik dalam tata kelola dan pencatatan keuangan dan manfaatnya.

3. Pengenalan konsep pengelolaan keuangan kopontren yang baik secara mendalam kepada para pengurus kopontren melalui presentasi makalah dan kasus-kasus yang up to date. 
4. Mengadakan diskusi untuk dapat menghasilkan timbal balik mengenai pencatatan keuangan dengan bukti secara kronologis dan kendalanya dalam mengelola keuangan.

5. Pelatihan aplikasi teknologi informasi digital berbasis smartphone dengan tujuan semua pencatatan keuangan dapat dilakukan dengan baik dan tertata rapi.

Kopontren yang menjadi mitra dalam kegiatan IPTEKS ini berpartisipasi aktif dalam setiap kegiatan yang diselenggarakan. Dalam pencatatan keuangan, mitra berpartisipasi dalam pencatatan keuangan secara digital. Sedangkan dalam kegiatan pelatihan, disamping berpartisipasi sebagai peserta, mitra berperan dalam menyediakan tempat pelatihan, ikut mensosialisasikan program pelatihan yang akan dilaksanakan kepada kopontren lain dan ikut bekerja sama dengan tim dalam mengadakan konsumsi pelatihan. Sehingga partisipasi mitra sangat mendukung terhadap pelaksanaan program kegiatan IPTEKS ini secara keseluruhan.

\subsection{Realisasi Pemecahan Masalah}

1. Pelaksanaan Kegiatan

Pembentukan dan pendampingan kelompok santri pengelola koperasi yang dapat mengatasi kesulitan dalam pencatatan keuangan, pencatatan persediaan dan manajerial koperasi.

1. Pelatihan tentang pendidikan kewirausahaan syariah dan aspek manajerial koperasi.

2. Penguasaan praktek penerimaan dan pengeluaran serta mencatat dengan benar jumlah barang melalui kartu persediaan.

3. Menambah pengetahuan pengurus atau pengelola koperasi pondok pesantren tentang perkembangan pengelolaan keuangan dan tata kelola koperasi

4. Mendemonstrasikan penggunaan software aplikasi teknologi informasi digital berbasis smartphone dalam kegiatan kopontren

5. Pendampingan penggunaan aplikasi digital smartphone.

2. Materi Pelatihan dan Instruktur

Kegiatan PKM yang telah ditetapkan ini, memerlukan beberapa jenis kepakaran atau keahlian. Jenis keahlian yang dibutuhkan yaitu: (1) bidang akuntansi; (2) bidang manajemen; dan (3) bidang teknologi informasi. Sehingga untuk keberhasilan program kegiatan yang dilaksanakan, maka keanggotaan tim pengabdi ini terdiri dari beberapa dosen dengan bidang keahlian yang dibutuhkan serta dibantu oleh beberapa mahasiswa dan teknisi.

Tabel 1. Keahlian Tim dalam Pelaksana Kegiatan Ipteks

\begin{tabular}{|l|l|l|}
\hline No & \multicolumn{1}{|c|}{ Nama } & \multicolumn{1}{|c|}{ Keahlian } \\
\hline 1 & $\begin{array}{l}\text { M. Eka Syahputra, Amd dan Mujahid, } \\
\text { ST }\end{array}$ & $\begin{array}{l}\text { Komputerisasi Akuntansi Ms.Excell } \\
\text { dan Aplikasi Android }\end{array}$ \\
\hline 2 & Yunika Murdayanti, M.Si, M.Ak & Manajemen Keuangan \\
\hline 3 & Susi Indriani,M.SAk & Akuntansi Keuangan \\
\hline
\end{tabular}




\subsection{Rancangan Evaluasi}

Kegiatan observasi dilakukan secara langsung oleh tim pelaksana. Observasi berupa hasil kerja peserta terhadap pengelolaan koperasi yang baik dan pemanfaatan aplikasi teknologi informasi digital smartphone dalam operasional kopontren. Secara rinci rancangan evaluasi terdiri dari peningkatkan pengelolaan keuangannya sendiri sehingga dapat menghasilkan suatu struktur modal keuangan yang baik, peningkatan kemampuan keterampilan manajerial baik dari tata kelola koperasi dan keuangan, peningkatkan keahlian menggunakan teknologi informasi digital serta mampu mengaplikasin pencatatan keuangannya secara digital, pengelolaan sumber daya baik di dalam dirinya sendiri maupun diluar dirinya untuk menghasilkan kemandirian ekonomi kopontren, peningkatan keuletan dan ketelitian dalam melakukan menghitung jumlah persediaan dan pencatatan keuangan, penguasaan pendidikan kewirausahaan syariah (ISIEMENT), peningkatan kreatifitas, adanya pemisahan tugas yang jelas dengan prosedur tertulis tugas pokok dan fungsi masing-masing jabatan serta kemampuan menjalankan tugas dengan baik sesuai dengan bidangnya.

\section{HASIL DAN PEMBAHASAN}

\subsection{Hasil}

Pelaksanaan kegiatan pengabdian ini mengikuti aktivitas pelaksanaan penelitian tindakan yang terdiri dari Perencanaan, Persiapan, Pelaksanaan (tindakan), Observasi dan Evaluasi. Kegiatan pengabdian dilakukan sesuai dengan waktu yang telah disepakati, maka para tim pengabdian kepada masyarakat dari FE UNJ melakukan pelatihan yang dilaksanakan selama 3 hari yaitu hari jumat sampai dengan hari minggu, tanggal 23 - 25 agustus 2019 bertempatkan di lokasi Kopontren Daarul Rahman di Jln Cipedak Jagakarsa, Kav DKI Jakarta selatan. Adapun materi tersebut disusun sebagai berikut :

Tabel 2 Susunan Acara Pelatihan

\begin{tabular}{|l|l|lrr|}
\hline \multicolumn{1}{|c|}{ Hari dan Tanggal } & Waktu & \multicolumn{3}{|c|}{ Kegiatan } \\
\hline Jumat, 23 Agustus 2019 & $08.00-13.00$ & $\begin{array}{l}\text { Pengenalan pengelolaan keuangan } \\
\text { kewirausahaan syariah dan akuntansi } \\
\text { persediaan }\end{array}$ \\
\hline Sabtu, 24 Agustus 2019 & $08.00-14.30$ & $\begin{array}{l}\text { Akuntansi Persediaan dan Laporan } \\
\text { Keuangan Syariah dalam Praktek Microsoft } \\
\text { Excell }\end{array}$ \\
\hline $\begin{array}{l}\text { Minggu, 25 Agustus } \\
2019\end{array}$ & $08.00-14.30$ & $\begin{array}{l}\text { Akuntansi Persediaan dan Laporan } \\
\text { Persediaan dalam Praktek Aplikasi berbasis } \\
\text { Smartphone }\end{array}$ \\
\hline
\end{tabular}


Hari 1 : Pengenalan pengelolaan keuangan kewirausahaan syariah dan akuntansi persediaan.

Pada pelaksanaan pelatihan hari 1, pelatihan lebih memfokuskan kepada pengertian pentingnya persediaan dan laporan yang wajib dibuat sesuai standar keuangan. Manfaat serta pentingnya pencatatan yang baik dari setiap entitas ekonomi akan membuat entitas tersebut mempunyai kemampuan dan efektifitas tinggi dalam produktifitas kinerja keuangan. Dasar pencatatan administrasi barang dan pencatatan keuangan yang sesuai standar pelaporan keuangan akan meminimalisir kesalahan yang biasa terjadi karena human error dan hal lainnya. Berdasarkan kondisi koperasi pesantren Daarul Rahman yang bergerah pada usaha dagang barang kebutuhan konsumsi para santri serta mekanisme pembayaran tunai maka pencatatan keuangan juga relatif sederhana. Meskipun begitu konsep pengaplikasian pencatatan keuangan harus dijembatani dengan bahasan umum yang sederhana saja sebagai pengantar konsep dan difokuskan dengan pendekatan aplikatif langsung dengan sistem pada keesokan harinya.

Pada hari pertama didapati beberapa informasi yang bersifat tekhnis dalam pengelolaan koperasi selama ini diantaranya adalah belum terdpat kartu persediaan untuk digunakan mencatat jumlah persediaan yang berada di gudang dan ruang utama koperasi. Ditemukannya jumlah yang tidak sama setiap dilakukannya perhitungan persediaan barang koperasi sehingga mengakibatkan jumlah penerimaan dan pengeluaran koperasi tidak seimbang. Serta minimnya pengetahuan melek teknologi informasi sehingga masih ditemukan kesalahan pencatatan tidak disengaja (human error). Pencatatan keuangan yang dilakukan masih dilakukan secara manual dengan mencatat pada buku kas umum. Pada tiap periode tertentu yang waktunya tidak tetap dilakukan pelaporan keuangan koperasi berdasarkan pencatatan buku kas umum. Jadi laporan keuangan yang dihasilkan selama ini masih sederhana dan hanya beisikan laporan kas masuk dan kas keluar saja. Informasi tersebut menjadi tambahan data untuk penekanan pemhaman atas aplikasi program yang akan ditawarkan untuk diaplikasikan pada kegiatan koperasi Daarul Rahman.

Hari 2 : Akuntansi Persediaan dan Laporan Keuangan Syariah dalam Praktek Program Komputer dengan Microsoft Excell

Hari ke dua dilakukan pengenalan aplikasi excell yang merupakan program yang paling mudah digunakan dan dapat diaplikasikan oleh semua kalangan serta dapat mengakomodasi program pelaporan keuangan sederhana. Aplikasi program komputer menggunakan ms Excel yang merupakan salah satu program perghitungan yang dapat dipergunakan oleh koperasi sebagai salah satu aplikasi untuk membuat pencatatan transaksi dan pelaporan keuangan atas kegiatan ekonomi yang terjadi. Pada aplikasi ini tim PKM UNJ membantu aplikasi berbasi excell untuk mampu menghasilkan laporan - laporan yang dibutuhkan seperti laporan persediaan, Laporan Laba / Rugi dan Laporan Posisi Keuangan. 
Program berbasis Excell ini diharapkan dapat membantu pembuatan laporan keuangan koperasi yang memenuhi standar pelaporan keuangan entitas bisnis serta mempunyai hasil pencatatan dan pelaporan dengan sistem akurasi tinggi, efisien dan efektif. Proses pencatatan dan pelaporan transaksi koperasi yang terjadi sudah berbasis tekhnologi dengan kemudahan dan kecepatan yang efektif dan bisa langsung bisa digunakan langsung. Laporan keuangan dapat dihasilkan kapan saja dan bisa dilakukan hanya dengan menekan tombol laporan yang diinginkan.

Pelatihan hari kedua juga dilengkapi dengan modul pelatihan yang berisikan langkahlangkah dalam melakukan pencatatan transaksi yang mendetail dengan berbagai contoh kasus, seperti penjualan, pembelian, retur barang, penambahan item produk, barang yang sama namun mempunyai harga yang berbeda karena waktu pembelian yang berbeda.

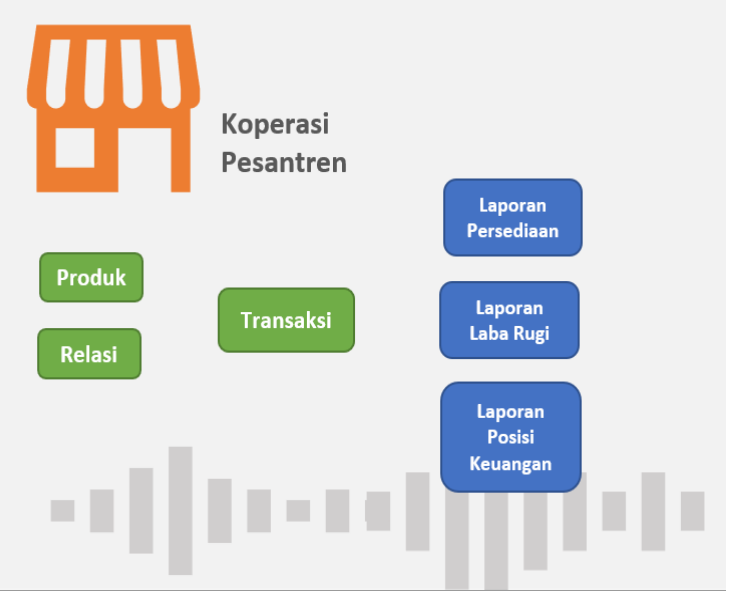

Gambar 5. Menu Program Keuangan Kopontren Ms.Excell

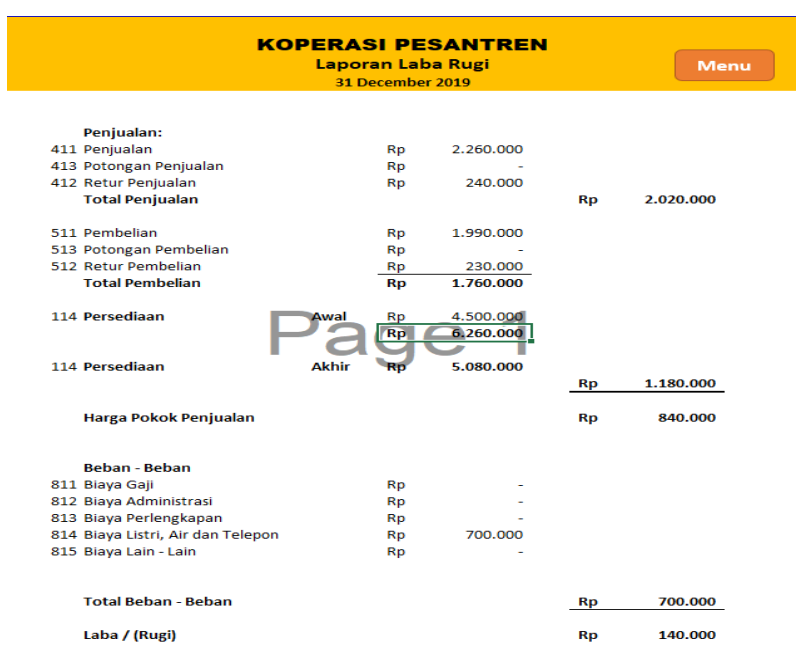

Gambar 6. Format Laporan Laba Rugi yang dihasilkan oleh Program Ms. Excell 


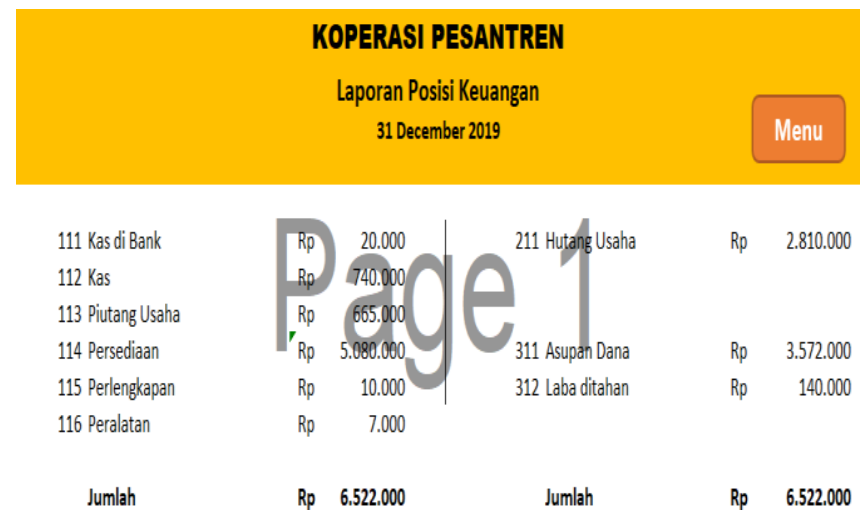

Gambar 7. Format Laporan Posisi Keuangan yang dihasilkan oleh Program Ms.Excell

Hari 3 : Akuntansi Persediaan dan Laporan Persediaan dalam Praktek Aplikasi berbasis Smartphone.

Hari ketiga pelatihan merupakan pelatihan yang memfokuskan pada penggunaan android untuk mempermudah pencatatan keuangan dalam hal transaksi masuk dan transaksi keluar pada persediaan barang dagang koperasi. Aplikasi android ini atau smartphone sudah terdaftar di google playstore yang bertujuan memudahkan para pengguna siapa pun pengelola koperasi dapat mendownload aplikasi ini sehingga memudahkan dalam melakukan perhitungan stok persediaan.

Pada praktek aplikasi berbasis smartphone ini intinya sama dengan program excell namun pada smartphone pelaporan keuangan belum terakomodasi, jadi proses pencatatan yang terjadi hanya akan memberikan informasi pada nilai persediaan yang akurat baik dalam jumlah <kuantitas> ataupun dalam nilai <rupiah>. Kelebihan berbasis smartphone adalah sangat mudah untuk diaplikasikan karena smartphone bukan lagi barang mewah dan merupakan tekhnologi yang sangat familiar di masyarakat. Penggunaan aplikasi inipun sangat mudah dipahami sehingga tingkat pengaplikasian akan sangat mudah pula jika memang berkenan menggunakannya. 


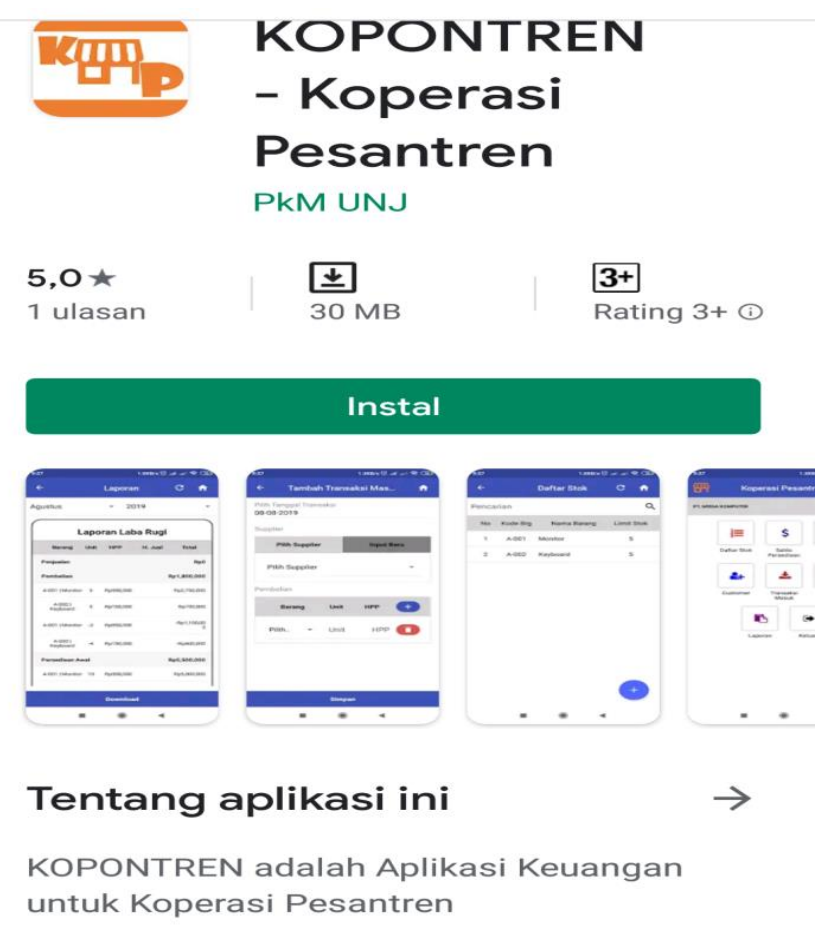

Gambar 8. Menu Aplikasi Pencatatan Persediaan berbasis Smartphone

Menu transaksi yang ditawarkan pada aplikasi berbasis smartphome relatif sma dengan yang ditawarkan pada program excell. Seperti transaksi penjualan, pembelian, retur barang, penambahan item produk, barang yang sama namun mempunyai harga yang berbeda karena waktu pembelian yang berbeda. Output pelaporan memang tidak terakomodasi dan hal ini yang menjadi pembeda kedua sistem aplikasi ini. Penggunaan kedua metode ini secara berdampingan bisa dilakukan secara berdampingan, yang perlu diperhatikan adalah cut off (waktu penentuan) periode pelaporan keuangan yang diinginkan. Manakala sudah ditetapkan maka harus dipastikan bahwa baik sistem android dan excell disamakan sehingga laporan bisa saling mendukung dengan akurat.

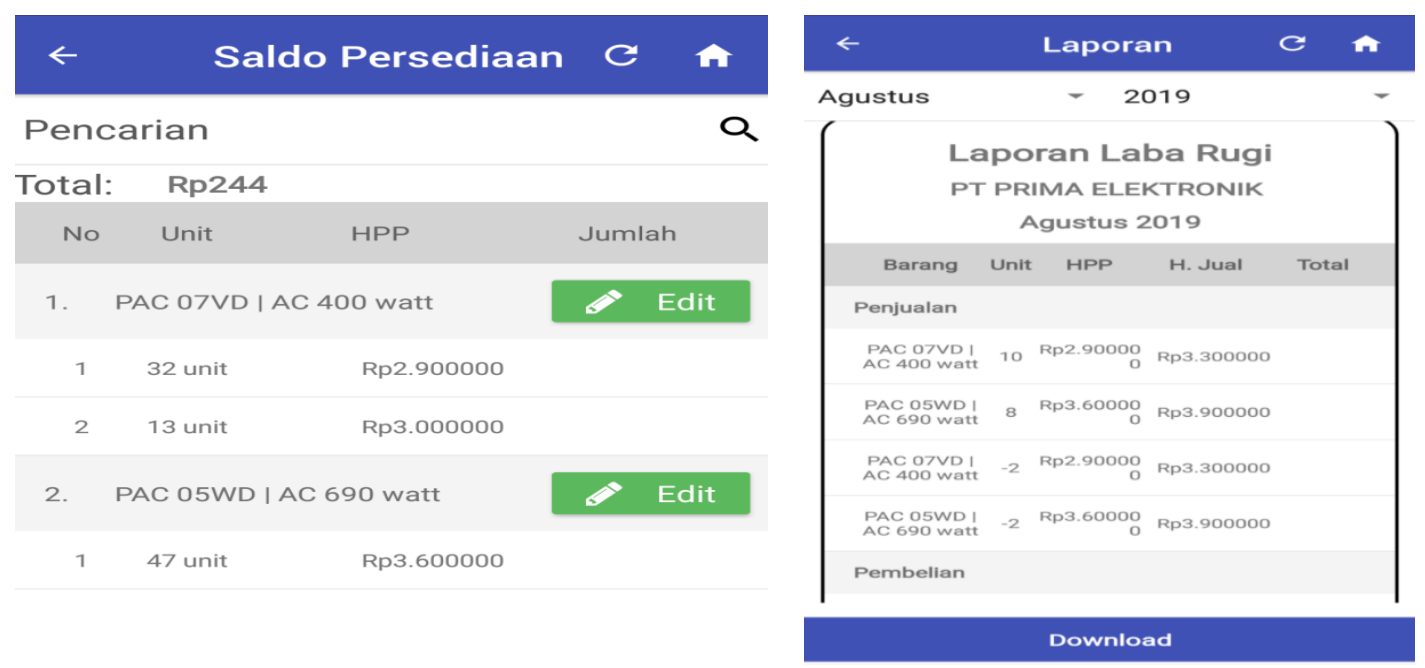

Gambar 9. Format Laporan persediaan berbasis Smartphone 


\subsection{Pembahasan}

Selama proses pelatihan berlangsung para peserta menunjukan antusisme yang sangat baik, yang ditunjukan dengan banyak peserta pelatihan yang berpartisipasi di setiap sesi tanya jawab, dan aktifnya diskusi yang berlangsung selama tanya jawab tersebut. Secara umum proses pelaksanaan pengabdian masyarakat diharapkan dapat meningkatkan pemahaman dan keterampilan koperasi pesantren pada manajemen koperasi Daarul Rahman, berdasarkan angket yang disebarkan kepada para peserta maka target peningkatan kemampuan SDM dalam bidang financial literacy sebesar $80 \%$ tercapai. Karena respon pertanyaan terkait ini menunjukkan tingkat respon yang tinggi dengan skala 4 dan 5. Sedangkan untuk peningkatan kemampuan SDM dalam tata kelola organisasi koperasi sebesar $75 \%$ belum dapat dipastikan karena pertanyaan di angket tidak mengakomodasi hal terssebut dikarenakan perlu ada masa observasi setelah pengplikasian sistem di lapangan dahulu . Untuk sementara didapati bahwa peningkatan kemampuan SDM dalam hal tata kelola koperasi mengalami peningkatan berdasarkan pertanyaan pada angket yang di sebar dengan respon rata-rata pada skala 4 . Berikut hasil yang diperoleh berdasarkan angket yang disebar :

a. Pelatihan pengetahuan pendidikan kewirausaahaan memanfaatkan komputer berbasis smartphone memiliki hasil :

1. Kemampuan kelompok sasaran meningkat $85 \%$ dalam bidang aplikasi koperasi digital smartphone

2. Kelompok sasaran mampu membuat pencatatan keuangan yang baik secara komputerisasi

b. Peningkatan kemampuan manajerial SDM memiliki hasil :

1. Peningkatan kemampuan SDM dalam bidang financial literacy sebesar $80 \%$.

2. Peningkatan kemampuan SDM dalam bidang manajemen produk jasa dan layanan keuangan syariah sebesar $75 \%$.

3. Peningkatan kemampuan SDM dalam tata kelola organisasi koperasi sebesar $75 \%$.

c. Pelatihan teknologi informasi digital berbasis smartphone sebagai sarana pengelolaan keuangan koperasi pondok pesantren memiliki hasil :

1. Kemampuan kelompok sasaran meningkat dalam bidang keuangan koperasi pesantren melalui aplikasi teknologi informasi digital sebesar $90 \%$.

2. Tersedianya media aplikasi teknologi komputer sebagai sarana perbaikan keuangan dan persediaan koperasi sebesar $85 \%$.

Peningkatan kemampuan penggunaan tekhnologi informasi berbasis komputer dengan sistem excel dan smartphone juga mengalami peningkatan. Hal ini ditunjukkan dengan antusisme yang terjadi pada saat pelatihan dan juga respon atas angket yang diberikan terkait kemudahan penggunaan tekhnolog informasi untuk diaplikasikan dalam bidang keuangan 
koperasi pesantren. Target kemampuan para peserta pelatihan dalam bidang keuangan koperasi pesantren melalui aplikasi teknologi informasi digital sebesar $90 \%$ tercapai ditunjukkan dengan terjawabnya respon rate indikator pertanyaan ini sebagian besar terletak pada skala 4 dan 5 .

Kemampuan manajerial mitra dalam hal pencatatan dan pelaporan keuangan menjadi target yang penting dikarenakan manfaat yang bisa diambil yaitu tertib administrasi serta transparansi dan akuntabilitas. Sistem pencatatan dan pelaporan sudah di desain dengan konsep friendly users (ramah pemgguna)pada basis excell dan smartphone. Tidak diperlukan lagi sumber daya manusia yang cakap secara ilmu ekonomi dengan adanya sistem ini untuk menghasilkan pelaporan keuangan sederhana yang memenuhi standar pelaporan keuangan sesuai ketentuan akuntansi yang berlaku. Sistem berbasis smartphone memberikan transaksi pencatatan sampai pemutakhiran data persediaan yang akurat yang mudah untuk diaplikasikan. Untuk program berbasis excell sudah dibuatkan suatu desain yang terintegrasi dari pencatatan transaksi keuangan, pemutakhiran nilai dan kuantitas persediaan serta satu set pelapaporan keuanan yang terdiri dari laporan persediaan, Laporan Laba / Rugi dan Laporan Posisi Keuangan. Pemahaman akan hal ini sangat baik dengan respon atas pertanyaan pada angket di jawab rata-rata pada skala 5, hal ini menunjukkan suatu hal yang baik mengingat pemahaman bidang akuntansi yang tidak begitu baik tapi mereka memahami kemudahan program yang ditawarkan dan bersedia melakukan perubahan.

Tabel 3. Evaluasi Pelatihan Aplikasi Keuangan dengan Ms. Excell

Berdasarkan Persepsi Responden

\begin{tabular}{|c|c|c|c|c|c|c|}
\hline \multirow[t]{2}{*}{ Indikator } & \multirow[t]{2}{*}{ Pernyataan } & 1 & 2 & 3 & 4 & 5 \\
\hline & & Fr & $\mathrm{Fr}$ & Fr & Fr & $\mathrm{Fr}$ \\
\hline \multirow[t]{5}{*}{ Materi } & Kejelasan materi pelatihan & & & 1 & 13 & 14 \\
\hline & Kualitas materi pelatihan & & & 1 & 10 & 17 \\
\hline & $\begin{array}{l}\text { Kesesuaian dengan tujuan } \\
\text { Pelatihan }\end{array}$ & & & 6 & 9 & 13 \\
\hline & $\begin{array}{ll}\text { Kemudahan penerapannya } \\
\text { pada praktek }\end{array}$ & & & 7 & 15 & 6 \\
\hline & Kesesuaian dengan kebutuhan & & & 6 & 16 & 6 \\
\hline \multirow[t]{4}{*}{$\begin{array}{l}\text { Instruktur/Tenaga } \\
\text { Pelatih }\end{array}$} & $\begin{array}{l}\text { Pengetahuan/ pemahaman } \\
\text { terhadap topik }\end{array}$ & & & 1 & 12 & 18 \\
\hline & $\begin{array}{ll}\text { Kemampuan } & \text { dalam } \\
\text { membawakan materi } & \end{array}$ & & & 2 & 14 & 12 \\
\hline & $\begin{array}{l}\text { Kemampuan memahami } \\
\text { masalah peserta }\end{array}$ & & & 2 & 9 & 17 \\
\hline & Penampilan Instruktur & & & 1 & 6 & 21 \\
\hline
\end{tabular}




\begin{tabular}{|l|l|l|l|l|l|l|}
\hline Sarana/ Prasarana & Ruang Teori & & & 4 & 3 & 21 \\
\hline & Listrik & & & 4 & 5 & 19 \\
\hline & Sarana Penunjang & & & 5 & 3 & 20 \\
\hline
\end{tabular}

Keterangan :

1 : Sangat Tidak Menarik, 2 : Tidak Menarik, 3 : Ragu, 4 : Menarik dan 5 : Sangat Menarik

Yang terakhir dan sangat penting adalah tersedianya media aplikasi teknologi komputer dan smartphone sebagai Sarana perbaikan keuangan dan persediaan bagi koperasi dan dapat diperoleh dengan mudah melalui google playstore. Dalam perjalanannya ke depan tentunya program ini masih perlu dikembangkan lagi untuk memenuhi kebutuhan transaksi pencatatan dan pelaporan keuangan yang lebih baik dan lebih komprehensif lagi. Peserta menyampaikan agar pelatihan serupa dapat dilaksanakan kembali. Dengan materi pelatihan yang dilengkapi dengan menerapkan sistem pencatatan persediaan dan pelaporan keuangan melalui aplikasi program komputer dan smartphone ini yang dirancang sesuai kebutuhan pengguna yaitu koperasi pesantren Daarul Rahman dan diharapkan mampu untuk memenuhi kebutuhkan standar pengelolaan sistem informasi koperasi pesantren yang bergerak di usaha jual beli serta mempunyai karaktersitik sama.

Tabel 4. Evaluasi Pelatihan Aplikasi Kopontren Berbasis Smartphone

Berdasarkan Persepsi Responden

\begin{tabular}{|c|c|c|c|c|c|c|}
\hline \multirow[t]{2}{*}{ Indikator } & \multirow[t]{2}{*}{ Pernyataan } & 1 & 2 & 3 & 4 & 5 \\
\hline & & $\mathrm{Fr}$ & $\mathrm{Fr}$ & $\mathrm{Fr}$ & $\mathrm{Fr}$ & $\mathrm{Fr}$ \\
\hline \multirow[t]{5}{*}{ Materi } & Kejelasan materi pelatihan & & & 1 & 8 & 13 \\
\hline & Kualitas materi pelatihan & & & 1 & 3 & 18 \\
\hline & $\begin{array}{l}\text { Kesesuaian dengan tujuan } \\
\text { Pelatihan }\end{array}$ & & & 2 & 6 & 14 \\
\hline & $\begin{array}{l}\text { Kemudahan penerapannya } \\
\text { pada praktek }\end{array}$ & & & 2 & 6 & 14 \\
\hline & Kesesuaian dengan kebutuhan & & & 2 & 6 & 14 \\
\hline \multirow[t]{4}{*}{$\begin{array}{l}\text { Instruktur/Tenaga } \\
\text { Pelatih }\end{array}$} & $\begin{array}{l}\text { Pengetahuan/ pemahaman } \\
\text { terhadap topik }\end{array}$ & & & 1 & 8 & 13 \\
\hline & $\begin{array}{ll}\text { Kemampuan } & \text { dalam } \\
\text { membawakan materi } & \end{array}$ & & & 1 & 3 & 18 \\
\hline & $\begin{array}{l}\text { Kemampuan memahami } \\
\text { masalah peserta }\end{array}$ & & & 1 & 7 & 14 \\
\hline & Penampilan Instruktur & & & 1 & 4 & 17 \\
\hline Sarana/ Prasarana & Ruang Teori & & & 3 & 4 & 15 \\
\hline
\end{tabular}




\begin{tabular}{|l|l|l|l|l|l|l|}
\hline & Listrik & & & 3 & 1 & 18 \\
\hline & Sarana Penunjang & & & 4 & 3 & 15 \\
\hline
\end{tabular}

Keterangan :

1: Sangat Tidak Menarik, 2 : Tidak Menarik, 3 : Ragu, 4 : Menarik dan 5 : Sangat Menarik

\section{KESIMPULAN}

Berdasarkan serangkaian kegiatan yang telah dilaksanakan pada koperasi pesantren Daarul Rahman maka kewirausahaan syariah berbasis Smartphone yang dilakukan tim PKM FE UNJ telah melakukan

1. Peningkatan pemahaman dan keterampilan pengelolaan aset koperasi pesantren pada tim manajemen koperasi Daarul Rahman melalui dikenalkannya sistem pencatatan dan pelaporan transaksi keuangan yang memenuhi standar pelaporan keuangan untuk transaksi sederhana bagi koperasi Daarul Rahman,

2. Peningkatan kemampuan penggunaan teknologi informasi berbasis excell dan smartphone yang dapat diaplikasikan dengan mudah oleh para pengelola koperasi Daarul Rahman.

3. Tersedianya media aplikasi teknologi komputer berbasis excell dan smartphone sebagai Sarana perbaikan keuangan dan persediaan bagi koperasi dan dapat diperoleh dengan mudah melalui google playstore.

Berdasarkan angket atas proses pelaksanaan PKM FE UNJ pada koperasi pesantren Daarul Rahman dengan tema kewirausahaan syariah berbasis Excell dan Smartphone maka didapati beberapa hal yang perlu mendapat perhatian untuk ke depannya.

1. Sarana dan prasarana pada saat pelaksanaan PKM mendapatkan respon antara 3 dan 4 . Hal ini dikarenakan ada beberapa kegiatan ponpes yang terjadi pada saat bersamaan proses PKM berlangsung sehingga beberapa perlengkapan untuk PKM sempat agak terhambat karena digunakan secara bergantian.

2. Koneksi antara sistem aplikasi berbasis excell dan smartphone yang dibuat belum mampu diintegrasikan secara koneksi langsung untuk memudahkan penggunaan aplikasi dan menjadi kebutuhan pengembangan sistem ke tahap berikutnya. Kedua sistem berjalan sendiri sendiri namun tetap dapat memberikan informasi yang akurat namun pada perangkat masing-masing saja. Jadi untuk menghasilkan pencatatan laporan keuangan yang lengkap harus menggunakan aplikasi berbasis excell. Jika tidak menghendaki adanya pelaporan keuangan dan hanya butuh up date informasi persediaan saja maka basis smartphone bisa menjadi pilihan. 


\section{UCAPAN TERIMA KASIH}

Tim Pengabdian Masyarakat FE UNJ mengucapkan terima kasih kepada Kementerian Ristek Dikti yang telah membantu mendanai kegiatan pengabdian kepada masyarakat ini, serta Ketua Lembaga Penelitian dan Pengabdian Masyarakat Universitas Negeri Jakarta beserta tim dan seluruh rekan-rekan dosen dan mahasiswa yang telah membantu dan bekerjasama sehingga pengabdian kepada masyarakat ini telah berjalan dengan lancar.

\section{DAFTAR PUSTAKA}

Arifin, Zainal dan Ikhsan Budi Riharjo. 2013. Pertanggungjawaban Keuangan Pondok Pesantren : Studi pada Yayasan Nazhatut Thullab. Jurnal Ilmu \& Riset Akuntansi. Vol. 3. No.11.Hal.1-13

Marsudi, Usman Arief, Siti Zahrok. 2011. Pengembangan Manajemen Koperasi di Pondok Pesantren Perguruan Islam Salafiah Kabupaten Blitar. Jurnal Sosial Humaniora. Volume 4 Nomor 2. Hal. 164-176.

Ninggar, Dwi. 2015. Excel2013 untukAkuntansi.Palembang: Maxikom

Rahmat, Biki Zulfikri, Lina Marlina dan Joni. 2017. IBP Pelatihan Ekonomi Syariah Dan Koperasi Pondok Pesantren Bagi Santri Riyadlul Ulum Wad Dakwah. Jurnal Pengabdian Siliwangi. Volume 3. Nomor 1. Hal. 156-159.

Tofik, Moch. 2008. Membuat Aplikasi Akuntansi dengan Microsoft Excell 2007. Jakarta : Mediakita.

Usman, Idris Muhammad. 2013. Pesantren sebagai Lembaga Pendidikan Islam. Jurnal Al Hikmah. Volume XIV no. 1.Hal. 101-119

Wahyudi, Alexander. 2017. Edupreneurship Sebagai Strategi Daya Saing Usaha Mikro, Kecil, dan Menengah Di Jawa Timur Menghadapi MEA. Accounting and Management Journal. Volume 1 Nomor 1. Hal. 55-62.

Yakin, Nurul. 2014. Studi Kasus Pola Manajemen Pondok Pesantren Al-Raisiyah Di

Kota Mataram. Ulumuna Jurnal Studi Keislaman, Volume 18 Nomor 1. Hal.199-220 https://economy.okezone.com/read/2017/11/16/320/1815071/berdayakan-62-pesantren-bigulirkan-kerjasama-ekonomi-syariah diakses pada tanggal 15 maret 2018 http://pipnews.co.id/2017/09/26/kementerian-koperasi-dorong-santri-rintis-wirausaha diakses pada tanggal 15 maret 2018 